UNRAM Law Review is licensed under a Creative Commons Attribution 4.0 International License, which permits unrestricted use, distribution, and reproduction in any medium, provided the original work is properly cited. p-ISSN: 2548-9267 | e-ISSN : 2549-2365, Open Access at : http://unramlawreview.unram.ac.id/index.php/ulr

\begin{tabular}{c|c|c|c|c|}
\hline Volume & Issue & Page & October & p-ISSN: 2548-9267 \\
\hline 4 & 2 & $112-122$ & 2020 & e-ISSN : 2549-2365
\end{tabular}

\title{
The Complexity Problem on the Law Enforcement by Indonesian Police Agency during the COVID-19 Pandemic
}

\author{
Dwi Putri Hardiani \\ Faculty of Law, Diponegoro University, Semarang, Indonesia \\ E-mail: dwiputrihardiani8@gmail.com \\ Nyoman Serikat Putra Jaya \\ Faculty of Law, Diponegoro University, Semarang, Indonesia \\ E-mail: putrajaya1984@yahoo.co.id
}

\begin{abstract}
In Indonesia, the COVID-19 pandemic can be a fundamental concern if it is not able to overcome its impact. This pandemic considered to be very influential in affecting and disturbing several fundamental aspects of a country, such as health, economic, legal aspect, defense and security, and etc. This study examined the complexity problem of law enforcement by the police officer during the COVID-19 pandemic. The method of this researchusesnormative legal research by prioritizing secondary data that analyzed descriptive qualitative analysis techniques. The results of this study indicate that the police are referred to the law that lives in the community because of the work of the police plays an important role in maintaining the security and defense of the community, the law enforcement, as well as providing protection, protection, and services to the community. This has placed the police in dealing with various dynamics of social changing including the current COVID-19 pandemic. However, the problem with police law enforcement in the current COVID-19 pandemic arises from the implementation of Large-Scale Social Restrictions (PSBB) policy, the complexity problem in law enforcement on PSBB, and the choice to the possible solutions.
\end{abstract}

Keywords: Law Enforcement; Police; COVID-19; Indonesia

\section{INTRODUCTION}

The countries in the world have been appalled by the COVID-19 pandemic, with the spreading of Corona Virus Disease 2019 (COVID-19) throughout the world. ${ }^{1}$ COVID-19 is caused by a new type of Corona Virus named SARS-CoV-2. ${ }^{2}$ The COVID-19 outbreak was first detected in Wuhan City, Hubei Province, China in December 2019, and was declared as a pandemic by the World Health Organization (WHO) in March 2020. ${ }^{3}$

\footnotetext{
${ }^{1}$ Elissa Driggin, et al. (2020). Cardiovascular considerations for patients, health care workers, and health systems during the COVID-19 pandemic. Journal of the American College of Cardiology, 75(18), 2352-2371, p. 1353.

${ }^{2}$ Neeltje Van Doremalen, et al. (2020). Aerosol and surface stability of SARS-CoV-2 as compared with SARSCoV-1. New England Journal of Medicine, 382(16), 1564-1567, p. 1564.

${ }^{3}$ Dalinama Telaumbanua. (2020). Urgensi Pembentukan Aturan Terkait Pencegahan Covid-19 Di Indonesia. QALA MUNA: Jurnal Pendidikan, Sosial, dan Agama, 12(1), 59-70, p. 64.
} 
The SARS-CoV-2 virus is thought to be spread among people primarily through respiratory droplets produced during coughing. ${ }^{4}$ This spark can also be produced from sneezing and normal breathing. Also, the virus can spread by touching the surface of a contaminated object and touching someone's face. COVID-19 is most contagious when a person who suffer from it along with the symptoms, although the spread may occur before the symptoms appear. ${ }^{5}$ Common symptoms including fever, coughing, and shortness of breath. Complications can be pneumonia and severe acute respiratory disease. There is no specific vaccine or antiviral treatment for this disease, so that the suggestion on preventative measures such as washing hands, covering mouth when coughing, keeping a distance from each others, and monitoring and self-isolation for the people who is a suspect of infection. ${ }^{6}$

The COVID-19 pandemic has caused the global social and economic disruption, postponement or cancellation of sporting and cultural events ${ }^{7}$, and widespread concerns about shortages of goods which have prompted panic purchases. ${ }^{8}$ In Indonesia, the COVID-19 pandemic considered to be a fundamental concern for the country if the country cannot cope with the impact of this COVID-19. ${ }^{9}$ Because it is not impossible that the impact of this comprehensive approach can affect and disturb some of the fundamental aspects of a country, such as health, economy, law, education, defense, and other fundamental aspects. ${ }^{10}$

Currently, COVID-19 has penetrated all parts of the world including Indonesia. The rapid spread of COVID-19 because of its transmission ability which is from "human to human". In Indonesia, on July 14, 2020, there were 78,572 confirmed cases (positive) and 3,710 deaths. While globally, on July 14, 2020, there were 12,964,809 confirmed cases (positive) and 570,288 cases died. This has become an urgency for the government and related parties to formulate policies in order to deal quickly and appropriately. ${ }^{11}$

Therefore, as a preventive measure and an effort to accelerate the handling of the COVID-19 pandemic, the Government of Indonesia adopted a policy of Large-Scale Social Restrictions (PembatasanSosialBerskalaBesar/PSBB), in order to encourage people to carry out physical distancing or social distancing, namely restrictions on activities that are able to gather many people. This policy is contained under Government Regulation Number 21 of 2020 concerning Large-Scale Social Restrictions (PSBB). The Efforts to prevent and break the chain of distribution of COVID-19 in Indonesia require the discipline in many aspects, especially the social life of the community. In a pandemic situation, a strict discipline is needed for social life

${ }^{4}$ Valentyn Stadnytskyi, et al. (2020). The airborne lifetime of small speech droplets and their potential importance in SARS-CoV-2 transmission. Proceedings of the National Academy of Sciences, 117(22), 11875-11877, p. 11875.

${ }^{5}$ Alif Jumai Rajab, Muhamad Saddam Nurdin, \& Hayatullah Mubarak. (2020). Tinjauan Hukum Islam pada Edaran Pe merintah dan MUI dalam Menyikapi Wabah Covid-19. BUSTANUL FUQAHA: Jurnal Bidang Hukum Islam, 1(2), 156173 , p. 162.

${ }^{6}$ Zaharah, Galialldusovna Kirilova, \& Anissa Windarti. (2020). Impact of Corona Virus Outbreak Towards Teaching and Learning Activities in Indonesia. SALAM: Jurnal Sosial dan Budaya Syar-i, 7(3), 269-282, p. 173.

${ }^{7}$ Ikhsan, Hari Sutra Disemadi, Syukri Kurniawan, \& Pujiyono. (2020). Upaya Perlindungan Anak Dalam Peradilan Pidana Di Era Pemberlakuan "New Normal" Selama Pandemi COVID-19 Di Indonesia.Jurnal Ilmu Hukum, 9(2), 225-242, p. 227.

${ }^{8}$ Hari Sutra Disemadi \& Ali Ismail Shaleh. (2020). Banking credit restructuring policy amid COVID-19 pandemic in Indonesia." Jurnal Inovasi Ekonomi, 5(2).

9 Tauratiya. (2020). Overmacht: Analisis Yuridis Penundaan Pelaksanaan Prestasi Akibat Pandemi COVID-19. Jurnal Ilmiah Mizani: Wacana Hukum, Ekonomi Dan Keagamaan, 7(1), 49-58, p. 53.

${ }^{10}$ Nur Rohim Yunus. (2020). Kebijakan Covid-19, Bebaskan Narapidana dan Pidanakan Pelanggar PSBB. 'ADA $L A H, 4(1), 1-6$, p. 3.

${ }^{11}$ Kementrian Kesehatan Indonesia. (2020). Situasi Terkini Perkembangan Coronavirus Disease (COVID-19) 15 Juli 2020, Available from https://covid19.kemkes.go.id/situasi-infeksi-emerging/info-corona-virus/situasi-terkini-perkem bangan-coronavirus-disease-covid-19-15-juli-2020/\#.Xw72ligzbIU, (Accesed 17 July 2020). 
in the form of physical distancing. This method considered to be the most effective effort to prevent and reduce the spread of this virus.

The Government Regulation Number 21 of 2020 must be obeyed, while to ensure the compliance, the Indonesian police have placedin the frontline. In this context, in addition to medical staff, the police can be called the frontline in the effort to prevent the spread of COVID-19. The success of the PSBB depends on the awareness and discipline of the community, but to ensure that both are running, the role of the police is required. The role of the police, which is crucial and significant to prevent the spread of COVID-19, would certainly be an "additional" task that had never been suspected before. Police, on the one hand, has routine duties as a law enforcer and guardians of public order, while on the other hand, they are relied upon the implementation of PSBB policy. At the same time, all of police personnel in the field must also increase their vigilance because they are also likely to be infected with COVID-19. ${ }^{12}$

Previous research related to this research was conducted by DesyDwiKatrin in 2015 which focused on the role of the police in law enforcement against perpetrators of premeditated murder ${ }^{13}$; ParamitaPrananintyas, Hari Sutra Disemadi, and NinikZakiyah in 2020 focusing on the role of the police in enforcing business competition law; ${ }^{14}$ and Muhammad Yogi MaulanaSitompul, Rahmat, and JunindraMartua in 2020 focusing on the role of the police in preventing the misuse of religious defamation. ${ }^{15}$ Unlike the previous research, this research will focus on examining the complexity of law enforcement during the COVID-19 pandemic which can be seen from the aspects of PSBB implementation, the complexity of problems in implementing PSBB, and the choice of solutions that can be done.

\section{METHOD}

The research method used in this study is the normative legal research method. This normative legal research method is a typology of doctrinal researchers that uses the statutory approach method. ${ }^{16}$ The data used in this legal research are secondary data which is divided into primary legal materials such as laws and regulations, secondary legal materials, and tertiary legal materials such as legal research journals related to the problem being examined. ${ }^{17}$ Secondary data was obtained through library research techniques by searching, collecting, processing, and analyzed through qualitative analysis techniques to get conclusions.

\footnotetext{
${ }^{12}$ Sarah Nuraini Siregar. (2020). Politik Nasional: Polri di Masa Pandemi COVID-19, Available from http://www.poli tik.lipi.go.id/kolom/kolom-2/politik-nasional/1391-polri-di-masa-pandemi-covid-19-kompleksitas-masalah-penegakan hukum-dan-pilihan-solusi, (Accesed 28 June 2020).

${ }^{13}$ Desy Dwi Katrin. (2015). Peran Kepolisian Dalam Penegakan Hukum Terhadap Pelaku Tindak Pidana Pembunuhan Berencana. POENALE: Jurnal Bagian Hukum Pidana, 3(3), 1-11, p. 1.

${ }^{14}$ Paramita Prananintyas, Hari Sutra Disemadi, dan Ninik Zakiyah. (2020). The Indonesian Business Competition Law: How the Police Plays a Role? Jurnal Hukum Novelty 11 (1), 105-113, p. 105.

${ }^{15}$ Muhammad Yogi Maulana Sitompul, Rahmat, and Junindra Martua. (2020). Tinjauan Yuridis Tentang Peran Kepolisian Dalam Melakukan Pencegahan Penyalagunaan Tindak Pidana Penodaan Agama. Jurnal Pionir, 6(1), 127-131, p. 127.

${ }^{16}$ Marthsian Yeksi Anakotta, \& Hari Sutra Disemadi. (2020). Melanjutkan Pembangunan Sistem Keamanan Nasional Indonesia Dalam Kerangka Legal System Sebagai Upaya Menanggulangi Kejahatan Terorisme. Jurnal Keamanan Na sional, 6(1), 41-71, p. 46.

${ }^{17}$ Kornelius Benuf, \& Muhamad Azhar. (2020). Metodologi Penelitian Hukum sebagai Instrumen Mengurai Permasalahan Hukum Kontemporer. Gema Keadilan, 7(1), 20-33, p. 26.
} 


\section{ANALYSIS AND DISCUSSION}

\section{The Police as a Living Law in Society}

One of the law enforcement agencies in Indonesia is the police. ${ }^{18}$ Police are a matter of rights relating to the functions and institutions of the police by statutory regulations. ${ }^{19}$ Based on Article 4 of Law Number 2 of 2002 concerning the Police of the Republic of Indonesia, the police are essentially law enforcement officers in charge of and responsible for public order, safety, and security of the community. On July 1, 2020, the Indonesian police agency have turned 74 years old, a relatively young age. Since it born in 1945 after the independence of Republic of Indonesia, the police agency has been present in the community to maintain the security and order of the people, uphold the law, protect and serve the community. In its historical trajectory, the Police involved a lot in solving problems that occurred in the country, from escalating to ordinary to extraordinary threats.

The dynamics of the journey of the police forces began in 2002, by virtue ofthe decision of Consultative Assembly (TAP MPR RI Number VI/MPR/2000) at 2002 concerning the Separation of the Indonesian National Army and the Indonesian Police agency. This is one of the demands for the reform and future challenges for the police because since then, the police has become an independent civil institution with attribution authority according to Law No. 2 of 2002 to carry out its main task: maintaining security and public order; enforce the law; and provide protection, protection, and service to the community. ${ }^{20}$

Since becoming an institution with a civil status, the police must carry out their duties as bodyguards, even as drivers of democratic processes. A historical task that is not easy, especially because the contestation of discourses in public spaces is still going on tightly. Besides all members of the police also need enlightenment and uniformity of knowledge on this matter. Its status as a civil institution makes police an institution that will always interact with the community along with the dynamics of social changing. Therefore the police and the community must naturally cooperate in various aspects of life to face the dynamics of social change as a part of the globalization process. The concrete manifestation of the police as a civil institution can be seen from its role as a living law and guidance for the Indonesian people. ${ }^{21}$

The police are called living law because the duty of the police is to maintain the security and order of the community, uphold the law, and provide protection, protection, and service to the community. ${ }^{22}$ This has placed the police in dealing with various dynamics of social changing. One of the example is the existence of violations and/or crimes that threaten people's lives, even of course the police. However, all of that has become a risk of the task and role.

In the dynamics of social change, the police, law, and society are the three variables that will always be intertwined because the community will continue to intersect with the police where

\footnotetext{
${ }^{18}$ Kartika Sasi Wahyuningrum, Hari Sutra Disemadi, \&EkoSoponyono. (2020). Perlindungan Hak-Hak Penyidik Kepoli sian Yang Dituduh Melakukan Penganiayaan Kepada Tersangka. Jurisprudentie: Jurusan Ilmu Hukum Fakultas Sya riah dan Hukum, 7(1), 46-59, DOI, p. 48.

${ }^{19}$ Glenn Richard Pandelaki. (2018). Peran Polisi Dalam Pengendalian Massa Berdasarkan Undang-Undang Nomor 2 Tahun 2002 Tentang Kepolisian Negara Republik Indonesia. Lex Et Societatis, 6(5), 157-169, p. 161.

${ }^{20}$ Kabib Nawawi. (2010). Progresifitas Polisi Menuju Polisi Profesional. INOVATIF: Jurnal Ilmu Hukum, 2(3), 55-69, p.59.

${ }^{21}$ Marthsian Anakotta. (2020). Dirgahayu Polri ke-74 Tahun: Polisi sebagai Hukum yang Hidup dan Pandu bagi Mas yarakat Indonesia. Available from https://www.kompasiana.com/akaiano/5efc416a097f36156d4437b2/dirgahayu-pol ri-ke-74-tahun-polisi-sebagai-hukum-yang-hidup-dan-pandu-bagi-masyarakat-indonesia, (Accessed 14 Juli 2020).

${ }^{22}$ Marthsian Anakotta. (2020). Op.Cit.
} 
its obligation is maintaining the security and order of the people, law enforcement, as well as protectors, protectors, and public servants. ${ }^{23}$ This is similar to the statement of SatjiptoRahardjo (Professor of Progressive Law of UNDIP), who is familiarly called Prof. Tjip who states that more people intersect with police agencies because the police are law enforcement that is easily found in the open or on the streets. Thus, it also emphasizes that the essence of police duty is to carry out social control. ${ }^{24}$ In the current state and modern legal structure, these controls become part of the social controls exercised by the government. It is become bureaucratic, formal, and procedural. ${ }^{25}$ Correspondingly, the police can also be referred to as the guardians of the status quo. In a general sense, the meaning of social control is broader. Every attempt to influence and submit individual behavior to the norms of society in social control. ${ }^{26}$

In the current development of modern law, this control mechanism is primarily served, by the so-called "Criminal Justice System", and the police are one of the most important and frontline objector pillars. When carrying out their duties, the police can be said to be a living law because through the police, the law is carried out, just look at how the process in the criminal justice system, the police-public prosecutor, judge (court), and correctional institutions. ${ }^{27}$ The strand of this system shows that the police are the first door when the people intersect with the law. When an act of violation and/or crime occurs, the police will immediately investigate it, then the results of the investigation will be transferred to the prosecutor's office for the later trial by the judge. The end of the process is the penitentiary as an institution tasked with fostering the perpetrators of criminal acts so that when they are free they are ready for the community again. ${ }^{28}$

As a living law, the police not only enforce the law in the form of laws and regulations but also the law that lives and is recognized in society. Thus, the duties and roles of the police as a living law must also be able to know and fully understand every law that lives in the community. BardaNawawiArief (Professor of Criminal Law UNDIP) said that law is not only in its formal (written) form of legislation, but also must be in its material form (not written) in the form of living laws or norms that are recognized by the community. ${ }^{29}$

\section{The Complexity Problems of Law Enforcement by the Police Officer during the COV- ID-19 Pandemic}

The function of law enforcement carried out by the Police is inseparable from its function as stipulated under the Law No. 2 of 2002. According to Article 2 states that one of the function of the police is the function of the state government in the field of maintaining security and public order, law enforcement, protection, protection, and service to the community. Explicitly, this statement was reaffirmed as the duties and authority of the Police which is regulated

${ }^{23}$ Mahrus Ali. (2007). Sistem Peradilan Pidana Progresif; Alternatif dalam Penegakan Hukum Pidana. Jurnal Hukum Ius Quia Iustum, 14(2), 210-229, p. 221.

${ }^{24}$ Satjipto Rahardjo. (2005). HukumProgresif: Hukum yang Membebaskan. Jurnal Hukum Progresif, 1(1), 1-24, p. 12.

${ }^{25}$ Marthsian Anakotta. (2020). Op.Cit.

${ }^{26}$ H. Deni Nuryadi. (2016). Teori Hukum Progresif Dan Penerapannya Di Indonesia. Jurnal Ilmiah Hukum DEJURE: Kajian Ilmiah Hukum, 1(2), 394-408, p. 399.

${ }^{27}$ Asiyah Jamilah \& Hari Sutra Disemadi. (2020). Pidana Kerja Sosial: Kebijakan Penanggulangan Overcrowding Penja ra. Jurnal IUS Kajian Hukum dan Keadilan, 8(1), 26-38, p. 31.

${ }^{28}$ A. Sukris Sarmadi. (2012). Membebaskan Positivisme Hukum Ke Ranah Hukum Progresif (Studi Pembacaan Teks Hukum Bagi Penegak Hukum). Jurnal Dinamika Hukum, 12(2), 331-343, p. 339.

${ }^{29}$ Marthsian Anakotta. (2020). Op.Cit. 
under Article 13 of Law No. 2 of 2002. By virtue of the regulation above, the term security in the context of the duties and functions of the Police is "security and public order", where this term contains two meanings. ${ }^{30}$ First, as a dynamic condition of the community, as one of the prerequisites for the implementation of national development as a national goal which is marked by ensuring security, order, upholding the law, and maintaining peace. Secondly, security as the ability to foster and develop the potential and power of the community in preventing, preventing and overcoming all forms of violations of the law and other forms of interference that can cause public unrest. ${ }^{31}$

During the COVID-19 pandemic, the role of the Police was more emphasized in the second understanding because, during the PSBB, the Police assumed a law enforcement function that was reaffirmed through the Police Chief's Decree No. Mak/ 2/III/2020 concerning Compliance with Government Policies in Handling COVID-19. The notice was an initiative of the Police in supporting the government's policy regarding PSBB. ${ }^{32}$ The Indonesian Police Chief's announcement stated that the police fully supported government policies regarding the handling of COVID-19 and broke the chain of COVID-19 outbreaks in Indonesia through cracking down on people who were still gathered. The Police also focus on handling potential crimes when implementing PSBB, such as street crime, resistance to officers, problems in the availability of staples, and cybercrime. ${ }^{33}$ To support the enforcement aspects, the Police held a"Aman Nusa II" contingency 2020 operation. This operation was carried out from 19 March to 17 April 2020. The operational period could be extended based on the development of the situation on the ground. ${ }^{34}$

This task force has several sub-task forces. First, the Public Criminal Sub-Task Force in charge with the task to cracking down conventional crimes (theft, looting, robbery, criminal acts of natural disasters, and health quarantine crimes). ${ }^{35}$ Second, the Economic Sub task force in charge with the task to overseeing and cracking down on hoarding foodstuffs and medical devices, cracking down on antiseptic exporters, mask raw materials, personal protective equipment, and masks, as well as repression of drugs or medical devices that are not following the standard/distribution permit. ${ }^{36}$ Third, the Siberian Sub task force took an action against provocateurs and the spread of "hoax" related to handling COVID-19 pandemic. ${ }^{37}$

If you look at the substance of the information and the operations, the Indonesian Police function is more active in the area of action against violations rather than prevention. Moreover, the police area wants to be covered enti rely by the Police without considering technical difficulties in the field. The Police need to realize that from an internal perspective, there are still limitations (carrying capacity) of Indonesian Police (Polri) resources, such as the number

\footnotetext{
${ }^{30}$ Sarah Nuraini Siregar. (2020). Loc. Cit.

${ }^{31}$ Imas Novita Juaningsih. (2020). Penerapan Sanksi Pidana bagi Penimbun Masker di Indonesia Selama Masa Pandemi Covid-19. 'ADALAH, 4(1), 75-80, p. 78.

${ }^{32}$ Sri Wahyuni. (2020). Force Majeure Dan Notoir Feiten Atas Kebijakan PSBB COVID-19.” Jurnal Hukum Sasana, 6(1), $1-15$, p. 4.

33 CNBC Indonesia, Simak! Ini Maklumat Polri Untuk Penegakan Hukum PSBB, Available from https://www.cnbcin donesia.com/news/20200406131810-8-150024/simak-ini-maklumat-polri-untuk-penegakan-hukum-psbb, (Accesed 13 July 2020).

${ }^{34}$ Berita Satu. (2020). Polri Tegaskan Seluruh Polda Bantu Pemda Terapkan PSBB, Available from https://www.berita satu.com/nasional/619091-polri-tegaskan-seluruh-polda-bantu-pemda-terapkan-psbb (Accesed 14 July 2020).

${ }^{35}$ Sarah Nuraini Siregar. (2020). Op.Cit.

36 Mohammad Faisol Soleh. (2020). Penimbunan Alat Pelindung Diri pada Masa Pandemi Covid-19: Kajian Hukum Pi dana Bidang Perlindungan Konsumen. Undang: Jurnal Hukum, 3(1), 1-31, p. 21.

${ }^{37}$ Sarah Nuraini Siregar. (2020). Op.Cit.
} 
and ability of personnel on duty, coordination with stakeholders who are still weak, and so on. In many studies, the limitations above have not yet been fully resolved by the government itself. As stated under the Law No. 2 of 2002, the police function is not only enforcement, but also prevention through persuasive efforts that can involve the community. It seems that this is not a priority for the Police considering that in the announcement, the Police wanted to mobilize all the potential strengths to support the implementation of the PSBB policy.

But the main thing that cannot be ignored is that the pandemic has created very complex security problems. This should be observed by the police. This complexity at least visible from; First, fluctuations in crime rates throughout the pandemic and PSBB have both increased and decreased. In February there were 17,411 cases, in March it rose to 20,845 cases, then April decreased again to 15,322 cases. ${ }^{38}$ Even though in quantity it has decreased, there is a potential for crime in several sectors that should be watched out during the PSBB, such as street crime (robbery, and motor vehicle theft); Second, changes in criminal patterns during the pandemic. Roberts's study found that new forms of crime evolved as a use of the situation during the COVID-19 pandemic. This is confirmed from the polri's view that the crime that occurred during the PSBB was also caused by one of the economically affected communities during the COVID-19 pandemic. Criminals take advantage of the situation of social restrictions that cause the quiet environment to act.

Also, the Police need to take into account the other criminal patterns which not only occurred during the PSBB, but during the pandemic. For example, cases of theft and hoarding of medical devices, sale of fake drugs through organized crime, theft in an empty business sector, violations of public order due to disputes over medical issues, to community misconceptions about handling COVID-19. Until now, the misunderstanding is still ongoing amid the increasing positive cases of COVID-19. This has resulted in discrimination against medical workers and non-medical personnel to the rejection of bodies that are considered infected. The Indonesian Police has indeed demonstrated enforcement efforts through law enforcement, but it is still not comparable with the massive discrimination. ${ }^{39}$

This complexity needs to be observed by the police in determining the priority of law enforcement actions. In Stone's study, five main categories can become priority choices during the pandemic: a) enforce strict application of quarantine; b) protect medical personnel; c) cracking down on the hoarding of medical equipment and selling fake drugs; d) monitoring potential hoaks that can trigger social conflict; and e) arresting criminals who commit street crimes. Of these five categories, the position of the police is very important in developing strategies to deal with it and in setting priority issues to be addressed. ${ }^{40}$

According to the descpritions above, it can be assessed that the choice that can be made is open communication between the police and stakeholders. This form of communication is building a two-way dialogue with stakeholders (government and house of representatives/ DPR) ${ }^{41}$ The police needs to realistically states what they are doing, why, and the limitations and

${ }^{38}$ Sarah NurainiSiregar. (2020). Ibid.

${ }^{39}$ Devina Halim. (2020). Tugas Polri dalam Penanganan Covid-19: Imbau Warga Jaga Jarak hingga Tindak Penimbun Sembako, Available from https://nasional.kompas.com/read/2020/03/20/23012531/tugas-polri-dalam-penanga nan-covid-19-imbau-warga-jaga-jarak-hingga-tindak, (Accesed 14 July 2020).

${ }^{40}$ Cristopher Stone. (2020). Policing A Pandemic: How Police Were and Were Not Prepared For COVID-19, Available from https://www.worldpoliticsreview.com/articles/, (Accesed 10 July 2020).

${ }^{41}$ Ahmad Rofiq, Hari Sutra Disemadi, \& Nyoman Serikat Putra Jaya. (2019). Criminal Objectives Integrality in the Indo nesian Criminal Justice System. Al-Risalah, 19(2), 179-190, p. 185. 
uncertainties of the security situation to be faced, rather than claiming that all public security issues can be handled to protect reputation. The Police must also be prepared to negotiate their roles and prioritize law enforcement functions in certain categories. What functions can be reduced or limited and to what extent are their capacities and abilities to respond to requests for support from other institutions and the community. ${ }^{42}$ Through this communication, the security priority can be determined by the police with various considerations. Another option is community-based prevention. The implementation of PSBB in Bogor Regency can be an example. Prevention of the spread of this virus does not only depend on the mechanism of limitation in public areas (highways), but starts from the smallest community base (RT/RW, village, and district). The police can collaborate with the community by relying on the district level of police agency (Polsek) as the basis for early detection of potential security problems in the community. The role of Bhayangkara Trustees of Community Security and Order can be optimized to educate the public as preventing the emergence of hoaxes or stigmas about the COVID-19 pandemic.

further, the guideline of law enforcementcompiled by Interpol with the heading of COVID-19 Pandemic, Guidelines For Law Enforcement, the role of the police is expected not to be limited to the law enforcement. However, it plays a role in supporting efforts to overcome COVID-19. These roles include conducting patient tracing contact and tracking COVID-19 distribution, securing important infrastructure (hospitals and pharmacies) and crowd centers (malls, markets, airports, stations), and public education. ${ }^{43}$

\section{CONCLUSION}

The police called as a living law because of the duty of the police is to maintain the security and order of the community, uphold the law, and provide protection, protection, and services to the community. It has placed the police in dealing with various dynamics of social changing. One of the example is the existence of violations and/or crimes that threaten the lives of people during the COVID-19 pandemic. As a preventive measure and an effort to accelerate the handling of the COVID-19 pandemic, the Government of Indonesia adopted a PSBB policy in order to encourage people to carry out physical distancing or social distancing, namely restrictions on activities that are able to gather many people.

This policy raises new problems in the form of complex law enforcement by the police, such as fluctuations in crime rates during the COVID-19 pandemic and PSBB which have increased, changes in criminality patterns during the COVID-19 pandemic (for example cases of theft and hoarding of medical devices, sales of medicines fraud through organized crime, theft in an empty business sector, violations of public order due to disputes over medical problems, to community misconceptions about handling COVID-19). Therefore, according to this complexity, it is necessary to pay particular attention to the police in determining the priority of law enforcement actions. Then the choice that can be made is open communication between the police and stakeholders. This form of communication is building a two-way dialogue with stakeholders. The police needs to really state what they are doing, why, and the

\footnotetext{
${ }^{42}$ Sarah Nuraini Siregar. (2020). Op. Cit.

${ }^{43}$ Jamal Wiwoho. (2020). Tantangan Polri dalam Tatanan Kenormalan Baru, Available from https://mediaindonesia.com/ $\mathrm{read} /$ detail/324442-tantangan-polri-dalam-tatanan-kenormalan-baru, (Accesed 15 July 2020).
} 
limitations and uncertainties of the security situation that they are faceing, rather than claiming that all public security issues can be handled to protect their reputation. The police must also be prepared to negotiate their roles and prioritize law enforcement functions in certain categories.

\section{Bibliography}

Journal Articles:

Ahmad Rofiq, Hari Sutra Disemadi, \& Nyoman Serikat Putra Jaya. (2019). Criminal Objectives Integrality in the Indonesian Criminal Justice System. Al-Risalah, 19(2), 179-190.

AlifJumai Rajab, Muhamad Saddam Nurdin, \& Hayatullah Mubarak. (2020). Tinjauan Hukum Islam pada Edaran Pemerintah dan MUI dalam Menyikapi Wabah Covid-19. BUSTANUL FUQAHA: Jurnal Bidang Hukum Islam, 1(2), 156-173, p. 162.

Asiyah Jamilah \& Hari Sutra Disemadi. (2020). Pidana Kerja Sosial: Kebijakan Penanggulangan Overcrowding Penjara. Jurnal IUS Kajian Hukum dan Keadilan, 8(1), 26-38.

Dalinama Telaumbanua. (2020). Urgensi Pembentukan Aturan Terkait Pencegahan Covid-19 Di Indonesia. QALAMUNA: Jurnal Pendidikan, Sosial, dan Agama, 12(1), 59-70.

Desy Dwi Katrin. (2015). Peran Kepolisian Dalam Penegakan Hukum Terhadap Pelaku Tindak Pidana Pembunuhan Berencana. POENALE: Jurnal Bagian Hukum Pidana, 3(3), $1-11$.

Elissa Driggin, et al. (2020). Cardiovascular considerations for patients, health care workers, and health systems during the COVID-19 pandemic. Journal of the American College of Cardiology, 75(18), 2352-2371.

Glenn Richard Pandelaki. (2018). Peran Polisi Dalam Pengendalian Massa Berdasarkan Undang-Undang Nomor 2 Tahun 2002 Tentang Kepolisian Negara Republik Indonesia. Lex Et Societatis, 6(5), 157-169.

H. Deni Nuryadi. (2016). Teori Hukum Progresif Dan Penerapannya Di Indonesia. Jurnal Ilmiah Hukum DE JURE: Kajian Ilmiah Hukum, 1(2), 394-408.

Hari Sutra Disemadi \& Ali Ismail Shaleh. (2020). Banking credit restructuring policy amid COVID-19 pandemic in Indonesia." Jurnal Inovasi Ekonomi, 5(2).

Imas Novita Juaningsih. (2020). Penerapan Sanksi Pidana bagi Penimbun Masker di Indonesia Selama Masa Pandemi Covid-19. 'ADALAH, 4(1), 75-80.

Ikhsan, Hari Sutra Disemadi, Syukri Kurniawan, \& Pujiyono. (2020). Upaya Perlindungan Anak Dalam Peradilan Pidana Di Era Pemberlakuan "New Normal" SelamaPandemi COVID-19 Di Indonesia. Jurnal Ilmu Hukum, 9(2), 225-242.

Kabib Nawawi. (2010). Progresifitas Polisi Menuju Polisi Profesional. INOVATIF: Jurnal Ilmu Hukum, 2(3), 55-69.

Kartika Sasi Wahyuningrum, Hari Sutra Disemadi, \& Eko Soponyono. (2020). Perlindungan Hak-Hak Penyidik Kepolisian Yang Dituduh Melakukan Penganiayaan Kepada Tersangka. Jurisprudentie: Jurusan Ilmu Hukum Fakultas Syariah dan Hukum, 7(1), 46-59.

Kornelius Benuf, \& Muhamad Azhar. (2020). Metodologi Penelitian Hukum sebagai Instrumen Mengurai Permasalahan Hukum Kontemporer. Gema Keadilan, 7(1), 20-33. 
Mahrus Ali. (2007). Sistem Peradilan Pidana Progresif; Alternatif dalam Penegakan Hukum Pidana. Jurnal Hukum Ius QuiaIustum, 14(2), 210-229.

Marthsian YeksiAnakotta, \& Hari Sutra Disemadi. (2020). Melanjutkan Pembangunan Sistem Keamanan Nasional Indonesia Dalam Kerangka Legal System Sebagai Upaya Menanggulangi Kejahatan Terorisme. Jurnal Keamanan Nasional, 6(1), 41-71.

Mohammad FaisolSoleh. (2020). Penimbunan Alat Pelindung Diri pada Masa Pandemi Covid-19: Kajian Hukum Pidana Bidang Perlindungan Konsumen. Undang: Jurnal Hukum, 3(1), 1-31.

Muhammad Yogi Maulana Sitompul, Rahmat, and Junindra Martua. (2020). Tinjauan Yuridis Tentang Peran Kepolisian Dalam Melakukan Pencegahan Penyalagunaan Tindak Pidana Penodaan Agama. Jurnal Pionir, 6(1), 127-131.

Neeltje Van Doremalen, et al. (2020). Aerosol and surface stability of SARS-CoV-2 as compared with SARS-CoV-1. New England Journal of Medicine, 382(16), 1564-1567.

Nur Rohim Yunus. (2020). Kebijakan Covid-19, Bebaskan Narapidana dan Pidanakan Pelanggar PSBB. 'ADALAH, 4(1), 1-6.

Paramita Prananintyas, Hari Sutra Disemadi, dan Ninik Zakiyah. (2020). The Indonesian Business Competition Law: How the Police Plays a Role? Jurnal Hukum Novelty, 11(1), 105-113.

Satjipto Rahardjo. (2005). Hukum Progresif: Hukum yang Membebaskan. Jurnal Hukum Progresif, 1(1) 1-24.

Sri Wahyuni.(2020). Force Majeure DanNotoir FeitenAtas Kebijakan PSBB COVID-19.”Jurnal Hukum Sasana, 6(1), 1-15.

Sukris Sarmadi. (2012). Membebaskan Positivisme Hukum Ke Ranah Hukum Progresif (Studi Pembacaan Teks Hukum Bagi Penegak Hukum). Jurnal Dinamika Hukum, 12(2), 331-343.

Tauratiya. (2020). Overmacht: Analisis Yuridis Penundaan Pelaksanaan Prestasi Akibat Pandemi COVID-19. Jurnal Ilmiah Mizani: Wacana Hukum, Ekonomi Dan Keagamaan, 7(1), 49-58.

Valentyn Stadnytskyi, et al. (2020). The airborne lifetime of small speech droplets and their potential importance in SARS-CoV-2 transmission. Proceedings of the National Academy of Sciences, 117(22), 11875-11877.

Zaharah, Galia Ildusovna Kirilova, \& Anissa Windarti. (2020). Impact of Corona Virus Outbreak Towards Teaching and Learning Activities in Indonesia. SALAM: Jurnal Sosial dan Budaya Syar-i. 7(3), 269-282.

World Wide Web:

Berita Satu. (2020). Polri Tegaskan Seluruh Polda Bantu Pemda Terapkan PSBB, Available from:https://www.beritasatu.com/nasional/619091-polri-tegaskan-seluruh-poldabantu-pemda-terapkan-psbb (Accesed 14 July 2020).

CNBC Indonesia, Simak! Ini Maklumat Polri Untuk Penegakan Hukum PSBB, Available from https://www.cnbcindonesia.com/news/20200406131810-8-150024/simak-inimaklumat-polri-untuk-penegakan-hukum-psbb, (Accesed 13 July 2020).

Cristopher Stone. (2020). Policing A Pandemic: How Police Were and Were Not Prepared For 
COVID-19, Available from https://www.worldpoliticsreview.com/articles/, (Accesed 10 July 2020).

Devina Halim. (2020). Tugas Polri dalam Penanganan Covid-19: Imbau Warga Jaga Jarak hingga Tindak Penimbun Sembako, Available from https://nasional.kompas.com/ $\underline{\mathrm{read} / 2020 / 03 / 20 / 23012531 / \text { tugas-polri-dalam-penanganan-covid-19-imbau-warga- }}$ jaga-jarak-hingga-tindak, (Accesed 14 July 2020).

Jamal Wiwoho. (2020). Tantangan Polri dalam Tatanan Kenormalan Baru, Available from https://mediaindonesia.com/read/detail/324442-tantangan-polri-dalam-tatanankenormalan-baru, (Accesed 15 July 2020).

Kementrian Kesehatan Indonesia. (2020). Situasi Terkini Perkembangan Coronavirus Disease (COVID-19) 15 Juli 2020, Available from https://covid19.kemkes.go.id/situasiinfeksi-emerging/info-corona-virus/situasi-terkini-perkembangan-coronavirusdisease-covid-19-15-juli-2020/\#.Xw72ligzbIU, (Accesed 17 July 2020).

Marthsian Anakotta. (2020). Dirgahayu Polri ke-74 Tahun: Polisi sebagai Hukum yang Hidup dan Pandu bagi Masyarakat Indonesia. Available from https://www.kompasiana.com/ akaiano/5efc416a097f36156d4437b2/dirgahayu-polri-ke-74-tahun-polisi-sebagaihukum-yang-hidup-dan-pandu-bagi-masyarakat-indonesia, (Accessed 14 Juli 2020).

Sarah Nuraini Siregar. (2020). Politik Nasional: Polri di Masa Pandemi COVID-19, Available from http://www.politik.lipi.go.id/kolom/kolom-2/politik-nasional/1391-polri-dimasa-pandemi-covid-19-kompleksitas-masalah-penegakan-hukum-dan-pilihansolusi, (Accesed 28 June 2020).

Regulations:

Law Number 2 of 2002 concerning the Police of the Republic of Indonesia

TAP MPR RI Number VI/MPR/2000 of 2002 concerning the Separation of the Indonesian National Army and the Indonesian Police

Government Regulation Number 21 of 2020 concerning Large-Scale Social Restrictions

Police Chief's Decree No. Mak/ 2/III/2020 concerning Compliance with Government Policies in Handling COVID-19 